\title{
A randomized controlled trial of high parenteral protein feeding in septic children: the role of tumor necrosis factor-alpha-308 polymorphism
}

Gema Nazri Yanni, ${ }^{1}$ Amir Sjarifuddin Madjid, ${ }^{2}$ Aryono Hendarto, ${ }^{3}$ Sri Widia Azraki Jusman, ${ }^{4}$ Zakiudin Munasir, ${ }^{3}$ Hindra Irawan Satari, ${ }^{3}$ Iswari Setianingsih, ${ }^{5}$ Munar Lubis, ${ }^{1}$ Sudigdo Sastroasmoro ${ }^{3}$

Check for updates

pISSN: 0853-1773 • elSSN: 2252-8083 https://doi.org/10.13181/mji.oa.192104 Med J Indones. 2020;29:19-25

Received: July 6, 2017

Accepted: September 19, 2019

Authors' affiliations:

${ }^{1}$ Department of Pediatric, Faculty of Medicine, Universitas Sumatera Utara, Haji Adam Malik Hospital, Medan, Indonesia, ${ }^{2}$ Department of Anesthesiology, Faculty of Medicine, Universitas Indonesia, Jakarta, Indonesia, ${ }^{3}$ Department of Pediatric, Faculty of Medicine, Universitas Indonesia, Jakarta, Indonesia, ${ }^{4}$ Department of Biochemistry and Molecular Biology, Faculty of Medicine, Universitas Indonesia, Jakarta, Indonesia, ${ }^{5}$ Eijkman Institute for Molecular Biology, Jakarta, Indonesia

\section{Corresponding author:}

Gema Nazri Yanni

Department of Pediatric, Faculty of

Medicine, Universitas Sumatera Utara,

Jalan Dr. Mansyur No. 5, Medan 20155,

Indonesia

Tel/Fax: +62-61-8211633/

$+62-61-8219411$

E-mail: gema.nazri.yanni@gmail.com

\begin{abstract}
BACKGROUND Septic children cause high protein degradation and inadequate nutritional intake would worsen the outcomes. In addition, there are conflicting results of association between tumor necrosis factor-a (TNFA)-308 polymorphism and poorer outcomes. This study was aimed to investigate the impact of high protein feeding in septic children and to examine the role of the TNFA-308 polymorphism in outcome of sepsis.
\end{abstract}

METHODS In this randomized controlled trial, septic children were randomly assigned to receive either high protein feeding (amino acid of $4 \mathrm{~g} / \mathrm{kg}$ of body weight [kgBW]/ day) or standard nutrient (amino acid of $2 \mathrm{~g} / \mathrm{kgBW} /$ day) for three days in the pediatric intensive care unit of four hospitals in Indonesia. The patient's enrollment was done between April 2016 and May 2017. The primary outcome was the pediatric logistic organ dysfunction (PELOD) score. TNFA-308 polymorphism was investigated using restriction fragment length polymorphism method in both groups. PELOD score was analyzed as mean differences and gene polymorphism was analyzed with mortality in a subgroup.

RESULTS There were 40 children in each group. PELOD score on day-1 (22.4 versus 20.5, $p=0.429$ ), day-2 (20.5 versus 19.8, $p=0.815$ ), and day-3 (18.8 versus $19.8, p=$ 0.772 ) were not lower in high protein feeding compared to standard feeding. TNFA308 polymorphism had no role in mortality of both groups (high protein, $p=0.426$; standard, $p=0.456)$.

CONCLUSIONS From this study, researchers concluded that a high protein intervention did not significantly decrease the PELOD score, length of stay, and duration of ventilator use in both groups.

KEYWORDS children, high protein, outcome assessment, sepsis
Sepsis is a global issue due to its high morbidity and mortality. ${ }^{1}$ The mortality reached $7 \%$ of total children mortality. ${ }^{2}$ The incidence of pediatric sepsis was high. ${ }^{1}$ It was found in $19.3 \%$ of patients admitted to the pediatric intensive care unit (PICU) at Cipto Mangunkusumo Hospital with mortality rate of $54 \%{ }^{3}$ A critically ill children prone to have changes in protein metabolism, including an increase of protein degradation, a negative nitrogen balance, and a reduction of body mass. Protein catabolism is exacerbated by a inadequate nutritional intake, resulting in energy deficit which leads to a protein-energy malnutrition. It was found in $16-24 \%$ of critically ill children, resulting in worse outcomes. ${ }^{4}$

To avoid a loss of muscle mass due to catabolic process, an absorption of amino acids from the blood need to be enhanced by giving either intravenous or enteral route. This can trigger protein synthesis to compensate for the protein breakdown and increased 
amino acid oxidation. ${ }^{5}$ Nutritional support is important to prevent metabolic complications and maintain lean body mass. ${ }^{6}$ The amount of protein needed in critically ill children is higher than in healthy children, but the exact amount of protein required for septic children may not be ascertained.?

Besides, genetics have been strongly influenced the outcomes of septic patients as seen in wide variations of individual responses to infection. Some identified gene candidates play role in the inflammatory response, i.e., tumor necrosis factor- $\alpha$ (TNFA) and tumor necrosis factor- $\beta$ (TNFB) genes. Other gene candidates for sepsis and septic shock include an interleukin-1 receptor antagonist (ILRA), heat shock protein, IL-6, IL-10, CD14, toll-like receptor 4 (TLR4), and TLR2. ${ }^{8}$ TNFA-308 variance increases gene transcription compared with the wild-type allele, and will increase TNF- $\alpha$ macrophage secretion in vitro and is followed by an increase of TNF-a serum secretion in vivo. A study also found an allele that was associated with the worst outcomes from infectious diseases, including malaria, meningococcal disease, and celiac disease. ${ }^{9}$ In a multicenter study, patient with the TNF2 polymorphism (68\%) had higher TNF-a serum concentrations than those of TNF1 (52\%). TNF2 has a 3.7 times greater risk of death. ${ }^{10}$

Although nutritional support plays a significant role in the management of septic children, the requirement of protein in this condition remains unclear. Also, the role of TNFA-308 gene polymorphisms in sepsis and septic shock has been conflicted and not been widely studied in children. This study was aimed to investigate the impact of high protein feeding in septic children and to examine the role of TNFA-308 polymorphism in outcome of sepsis using the pediatric logistic organ dysfunction (PELOD) score.

\section{METHODS}

A randomized controlled trial was done in PICUs at four hospitals (Cipto Mangunkusumo Hospital Jakarta, Adam Malik Hospital Medan, Haji Hospital Medan, and Universitas Sumatera Utara Hospital Medan) between April 2016 and May 2017. The eligible criteria were children aged between one month and two years and admission to PICU due to sepsis. Patients with liver disease, obesity, hyperuricemia, and septic shock that did not resolve within 24 hours were excluded. Subjects' parents/guardians provided written informed consent for enrollment. This study was approved by the Ethics Committee of the Faculty of Medicine Universitas Indonesia (No: 1113/UN2.F1/ ETIK/2015).

\section{Study groups and randomization}

Patients diagnosed with sepsis based on the International Pediatric Sepsis Consensus Conference criteria were recruited by consecutive sampling in PICU. Block randomization was used with a block size of four.7 Randomization was carried out by one of the researchers and the given intervention was not blinded. The subjects were randomized into two groups: the intervention group receiving high protein feeding (amino acid of $4 \mathrm{~g} /$ kilogram of body weight [kgBW]/day) and the control group receiving standard protein feeding (amino acid of $2 \mathrm{~g} / \mathrm{kgBW} /$ day. The protein was given intravenously for three days using amino acid preparations (Aminosteril ${ }^{\circledR} 6 \%$ for age of $<12$ months and Aminofusin ${ }^{\circledR}$ Paed $5 \%$ for age of $\geq 12$ months). Patients who got fever during intervention was excluded for the analysis. Every patient got similar treatment based on their condition.

\section{Clinical procedure and laboratory investigation}

All children with sepsis underwent history taking and physical examinations, including nutritional status assessment according to the World Health Organization growth (for age of $<5$ years), Centers for Disease Control and Prevention (CDC) (for age of >5-18 years) chart, and other basic anthropometry. TNF- $\alpha$ and IL-10 serum level was examined within 12-24 hours of sepsis diagnosis. At the same time urine urea was also checked. The fluids and calories requirements were then calculated based on Holliday Segar and Schofield W formula. ${ }^{11}$ PELOD scores were measured on a numerical scale, including cardiovascular, respiratory, neurological, hematologic, hepatic, and renal systems. ${ }^{12}$ Each organ failure received a score of o to 20, with a total PELOD score of 71 . Weight monitoring, PELOD scoring, and nitrogen balance at 24 hours were done at the beginning of day-1 and were performed daily. Prealbumin level was only measured on day-1 and -3 . Mortality was observed until the patient had been discharged from PICU.

\section{Examination of TNFA polymorphism}

All subjects had TNFA-308 polymorphism examination. Specimens for DNA extraction were 
drawn from venous blood. The DNA extraction was conducted following the Wizard $^{\circledR}$ genomic DNA purification (Promega, USA) protocol. ${ }^{13}$ The TNFA308 gene was amplified using the polymerase chain reaction (PCR) method. The forward primer was 5'AGG CAA TAG GTT TTG AGG GCC AT -3' and the reverse primer was 3'-TC TCC CTG CTC CGA TTC CG. ${ }^{14}$ The PCR product was then visualized using electrophoresis to ensure a band of $107 \mathrm{bp}$. It was then incubated with a restriction enzyme, $\mathrm{Ncol}$ to detect polymorphism TNFA-308.

\section{Study outcomes}

The primary outcome was the daily PELOD score, based on clinical and laboratory findings assessed by the attending physician. ${ }^{14}$ Secondary outcome were length of stay and duration of ventilator use. Potential risk factors of the PELOD score were also examined, e.g. age, nutritional status, sex, nutritional interventions, and TNFA-308 gene polymorphism.

\section{Statistical analysis}

Data were recorded daily and analyzed with SPSS software, version 20 (IBM Corp, USA). PELOD score, length of stay, and duration of ventilator use was compared between high and standard protein feeding group. Numerical data were compared using an independent student's t-test or Mann-Whitney test. Risk factors of the PELOD score were also analyzed using those bivariate analysis, $p<0.05$ was considered statistically significant.

\section{RESULTS}

Among the 90 subjects, there were 5 subjects died, and only 85 subjects were allocated to both groups. Subjects with fever during intervention and fluid restriction was excluded, so that only 80 subjects continued until final analysis was performed, as shown in Figure 1. Table 1 shows baseline characteristics. Malnutrition was found in $15 \%$ of the standard protein

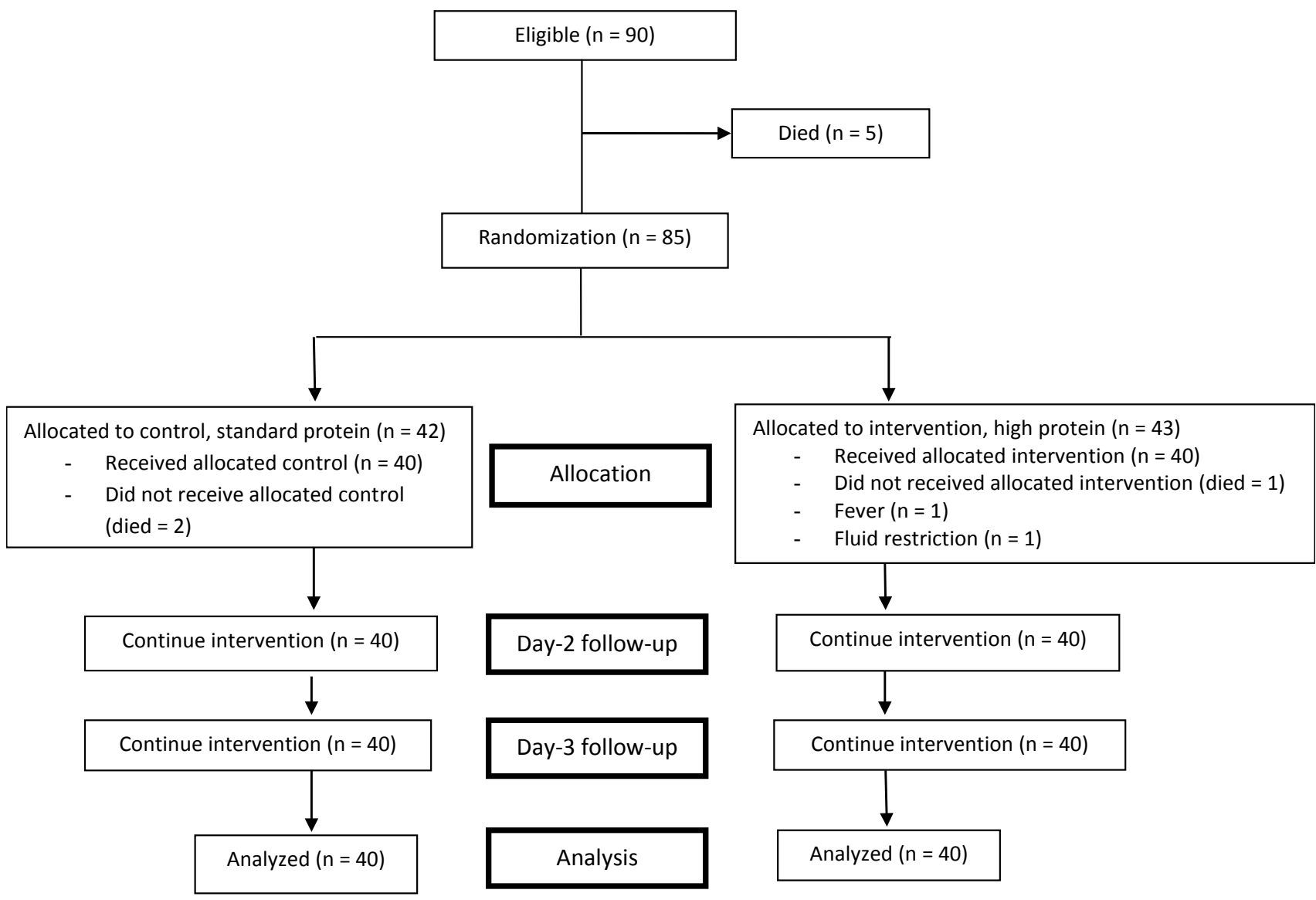

Figure 1. Recruitment scheme. The intervention group receiving high protein feeding (amino acid of $4 \mathrm{~g} / \mathrm{kilogram}$ of body weight [kgBW]/day) and the control group receiving standard protein feeding (amino acid of $2 \mathrm{~g} / \mathrm{kgBW} /$ day. The protein was given intravenously for three days using amino acid preparations (Aminosteril ${ }^{\circledR} 6 \%$ for age of $<12$ months and Aminofusin ${ }^{\circledR}$ Paed $5 \%$ for age of $\geq 12$ months) 
Table 1. Characteristics of subjects in both groups

\begin{tabular}{lcc}
\hline \multirow{2}{*}{ Characteristics } & \multicolumn{2}{c}{ Protein feeding } \\
\cline { 2 - 3 } & $\begin{array}{c}\text { Standard } \\
(\mathrm{N}=40)\end{array}$ & $\begin{array}{c}\text { High } \\
(\mathrm{N}=40)\end{array}$ \\
\hline Age (month), mean (SD) & $9.6(6.2)$ & $10.2(6.8)$ \\
Male sex, $\mathrm{n}(\%)$ & $25(63.0)$ & $28(70.0)$ \\
\hline Nutritional status, $\mathrm{n}(\%)$ & & \\
\hline Normal & $34(85.0)$ & $36(90.0)$ \\
\hline Moderate malnutrition & $5(12.5)$ & $3(7.5)$ \\
\hline Severe malnutrition & $1(2.5)$ & $1(2.5)$ \\
\hline Body weight (kg), mean (SD) & $8.3(2.9)$ & $8.2(2.9)$ \\
\hline TNF- $\alpha$ level (pg/ml), median (min-max) & $6.9(3.2-43.7)$ & $5.7(3-52.1)$ \\
\hline IL-10 level (pg/ml), median (min-max) & $13.1(1.4-80.1)$ & $10(2.8-62.7)$ \\
\hline TNF- $\alpha$ polymorphism, $\mathrm{n}(\%)$ & & $3(7.5)$ \\
\hline Heterozygous & $3(7.5)$ & $37(92.5)$ \\
\hline Normal & $37(92.5)$ & \\
\hline
\end{tabular}

$\mathrm{SD}=$ standard deviation; TNF- $\alpha=$ tumor necrosis factor- $\alpha$; IL-10=interleukin 10

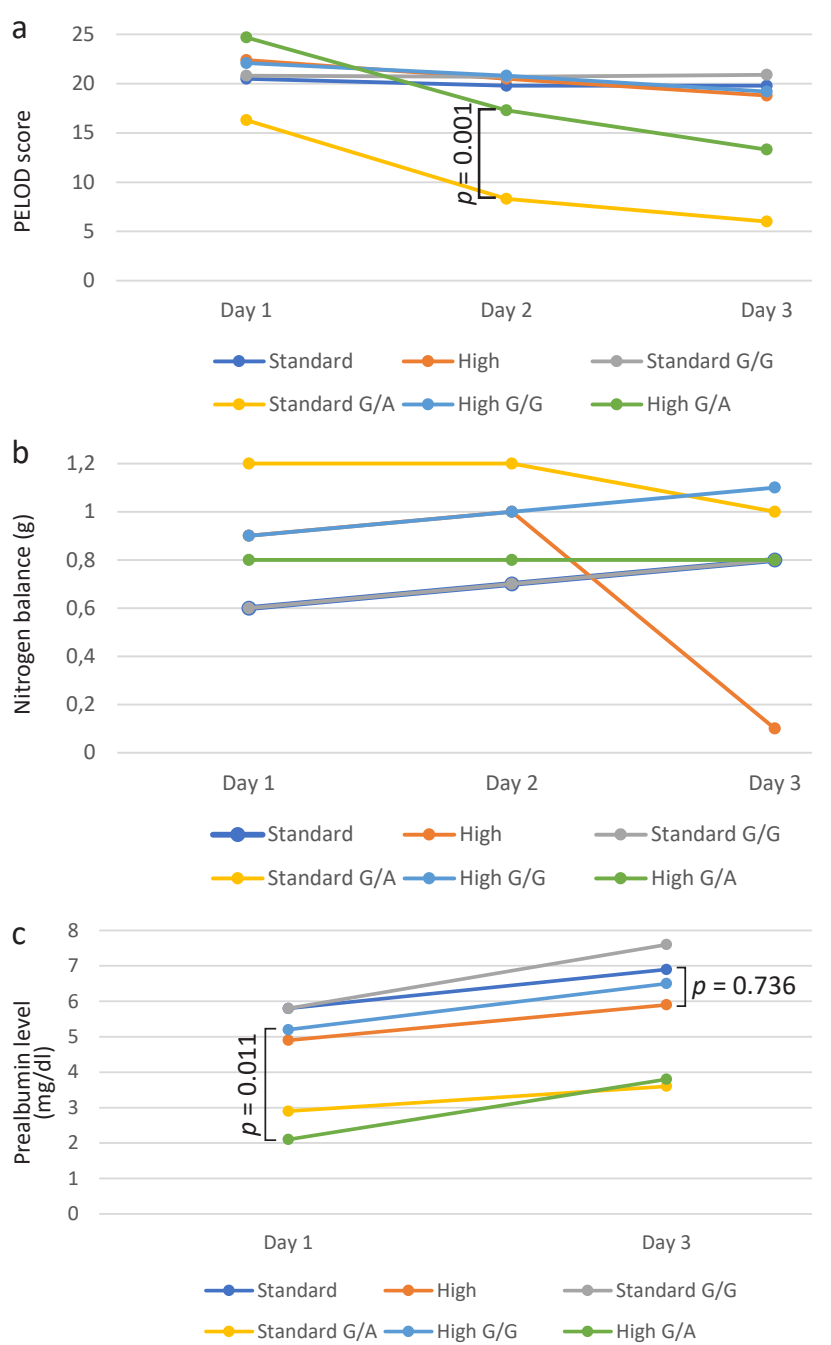

Figure 2. Outcomes of protein parenteral feeding groups based on TNFA-308 polymorphism in: (a) PELOD score (mean); (b) Nitrogen balance (median); (c) Prealbumin level (median). Standard=amino acid of $2 \mathrm{~g} / \mathrm{kgBW} /$ day; high= amino acid of $4 \mathrm{~g} / \mathrm{kgBW} /$ day; $\mathrm{G}=$ wild type TNFA allele; $\mathrm{A}=$ allele of TNFA-308 polymorphism group and $10 \%$ of the high protein group but mean of the body weights were similar between the two groups.

\section{Outcomes}

High protein feeding did not affect PELOD score in all three days. Prealbumin levels on day-3 was similar in both groups and only quantitative nitrogen balance which was higher in the high protein group of all three days. TNFA-308 polymorphism had different effect in both standard and high protein feeding groups. In the control group, TNFA-308 polymorphism affected the PELOD score on day- 2 . Meanwhile in the intervention group, it affected IL10 serum level, prealbumin level day-1, and duration of ventilator use. The trend of the PELOD score, nitrogen balance, and prealbumin level with the polymorphism was described on Figure 2.

Mortality rate in high protein feeding (22.5\%) was not lower than standard protein feeding (25\%) ( $p=$ $1.000)$. Length of hospital stay in high protein feeding (7 [4-27] days) was not shorter than standard protein feeding $(7[3-19]$ days $)(p=0.873)$. Duration of ventilator use was higher in high protein feeding ( $5[1-14]$ days) than in standard protein feeding (4 [1-27] days) ( $p=$ 0.458 ). From the bivariate analysis, no factors needed to proceed to multivariate analysis ( $p>0.25$ ).

All subjects with heterozygous TNFA-308 polymorphism were survived. No subject was found having homozygous gene (A/A) allele for TNFA-308 polymorphism (Figure 3). In both the standard and high protein feeding groups, TNF-a serum levels were 


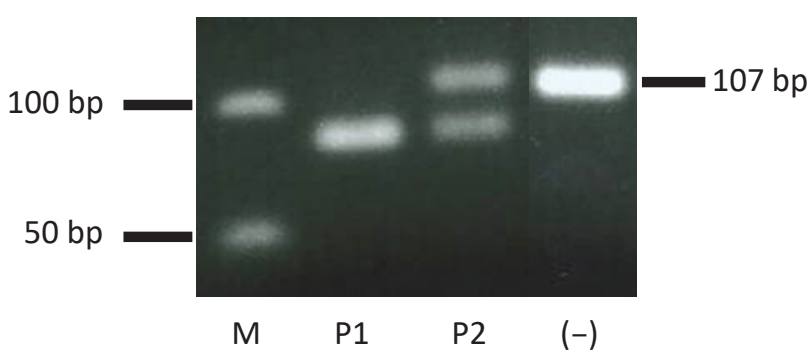

Figure 3. Restriction fragment length polymorphism (RFLP) of TNFA-308 polymorphism in all subjects. $M=$ marker, $\mathrm{P} 1=$ genotype $\mathrm{G} / \mathrm{G}$ (wild type), $\mathrm{P} 2$ =genotype $\mathrm{G} / \mathrm{A},(-)=$ negative control

not significantly higher in subjects with heterozygous TNFA-308 polymorphism than in wild type (Table 2 ).

\section{DISCUSSION}

The parenteral administration of high protein feeding in patients with sepsis is expected to create positive energy and nitrogen balance, control fluid and electrolytes homeostasis, maintain metabolic function, and deposit somatic and visceral proteins. ${ }^{11}$ In this study, high protein feeding did not improve PELOD score. Both groups had PELOD score $<20$ at day-3. It is considered important because PELOD score of $\geq 20$ possessed the risk of death 40.7 times, meanwhile PELOD score of 10-19 brought risk of death only 4.2 times. No study in critically ill children was found to associate protein feeding with sepsis prognosis. PELOD score was used as a prognosis of sepsis because it has high sensitivity, specificity, and accuracy to predict prognosis. ${ }^{15}$

No effect of high protein feeding on sepsis prognosis may be caused by some reasons. In premature infants, nutritional support with amino acids can improve nitrogen balance and growth, with increased protein synthesis. ${ }^{16}$ Several studies assessed the benefits of high protein intake (more than the recommended daily requirements) in surgical neonates $(2.5 \mathrm{~g} / \mathrm{kgBW} /$ day), ${ }^{17}$ and cystic fibrosis ( $5 \mathrm{~g} / \mathrm{kgBW} /$ day).${ }^{18}$ In this study, the estimation of a high protein of $4 \mathrm{~g} / \mathrm{kgBW} /$ day was based on a reference value of protein requirement 2-3 $\mathrm{g} / \mathrm{kgBW} /$ day for ages one month to 2 years and then added with the estimation of percentage of protein degradation. However, this estimation was not very accurate. Currently, a tracer method with isotopes is used to determine the balance of whole-body proteins for infants, children, and adults. This technique is very accurate for measuring protein kinetics but requires special equipment and expertise to perform. ${ }^{19}$ The tracer method with isotopes should be conducted for future research.

Higher amounts of protein were administered to reach protein target could be achieved earlier, and the negative impacts from the negative nitrogen balance could be avoided. On the other hand, the nitrogen balance was also higher in the high dose group. This implied that a high protein intake might reduce protein catabolism in critically ill children. The study mentioned the optimal time for measuring the PELOD score was on day-1, 2, 5, 8, 12, 16, and 18 of the PICU stay, ${ }^{20}$ while this study calculated the PELOD score on day-1, -2, and -3 during the intervention. This might be one of the reasons that measuring the PELOD score on day3 is not an optimal time, despite that the condition of the subject upon arrival at the PICU was different in severity and illness.

Stressful condition increases protein breakdown exceeding protein synthesis, resulting in a negative nitrogen balance. ${ }^{19}$ If this imbalance was continued, it would cause a loss of body mass and it would furtherly cause growth failure, malnutrition, and poor

Table 2. Risk factors and outcomes in subgroup analysis based on TNFA-308 polymorphism

\begin{tabular}{|c|c|c|c|c|c|c|}
\hline \multirow{4}{*}{ Parameter } & \multicolumn{6}{|c|}{ Protein nutrition intervention } \\
\hline & \multicolumn{3}{|c|}{ Standard } & \multicolumn{3}{|c|}{ High } \\
\hline & \multicolumn{2}{|c|}{ Median (min-max) } & \multirow{2}{*}{$p$} & \multicolumn{2}{|c|}{ Median (min-max) } & \multirow{2}{*}{$p$} \\
\hline & $\mathrm{G} / \mathrm{G}(\mathrm{N}=37)$ & $G / A(N=3)$ & & $\mathrm{G} / \mathrm{G}(\mathrm{N}=37)$ & $\mathrm{G} / \mathrm{A}(\mathrm{N}=3)$ & \\
\hline TNF- $\alpha$ & $4.1(3.9-43.7)$ & $6.9(3.2-32)$ & 0.456 & $5.7(3-52.1)$ & $6.9(5.3-8.1)$ & 0.426 \\
\hline IL-10 & $13.2(1.4-80.1)$ & $10.1(9.3-21.8)$ & 0.939 & $9.5(2.8-62.7)$ & $34.9(16.2-39.5)$ & 0.048 \\
\hline Length of stay (days) & $7(3-19)$ & $5(5-10)$ & 0.337 & $8(4-27)$ & $6(5-7)$ & 0.277 \\
\hline Duration of ventilator use (days) & $5(1-14)$ & $4(2-6)$ & 0.533 & $4(1-27)$ & $1(1-3)$ & 0.039 \\
\hline Mortality, n (\%) & $10(27.0)$ & $0(0.0)$ & 0.411 & $9(24.3)$ & $0(0.0)$ & 0.455 \\
\hline
\end{tabular}

TNF- $\alpha=$ tumor necrosis factor-alpha; IL=interleukin; $G=$ =wild type TNFA allele; $A=$ =allele of TNFA-308 polymorphism 
outcomes. ${ }^{21}$ In this study, nitrogen balance could be used to determine the protein requirements. It was seen that on the first day the nitrogen balance was significantly higher in high protein group and followed by clinical improvement. These results support previous studies where the high protein administration targeting nitrogen balance was achieved. On the other hand, our study failed to show a significantly lower mortality case on high protein group. Higher protein intake was not shown as an independent prognostic factor for children with sepsis. Another possible explanation is that the amount of protein administered was still less than the protein demand of the children with sepsis.

In this study, side effects of the high protein nutrient were not found; only one subject in the high protein group reported fever after one day of the intervention because of fluid limitation (the patient diagnosed with burns). There was also no report on adverse effect of central venous catheter insertion. This is in line with other studies that there were no adverse effects of high protein administration. ${ }^{22}$ The administration of a high protein nutrient is safe and has minimal side effects.

TNF-a plays an important role in aggravating the inflammatory process that manifests as hypotension, increased pulmonary capillary permeability, and disturbances of intestinal blood flow in sepsis, ${ }^{23}$ along with protein breakdown. ${ }^{22}$ TNFA-308 polymorphism affects the production of TNF- $\alpha$, thus altering the inflammatory process. ${ }^{10}$ Study in adults revealed that the mortality rate of patients with multiple organ dysfunction syndrome was influenced by TNFA-308 polymorphism. ${ }^{13}$

Study on TNFA-308 polymorphisms in septic patients is limited, especially in children. A study of 89 adults with multiple organ dysfunction syndrome reported that TNFA-308 gene polymorphisms were $35.2 \% \mathrm{~A} / \mathrm{A}$ with median plasma TNF- $\alpha$ of $10.6 \mathrm{pg} / \mathrm{ml}$ (4-252.8 pg/ml); 5.7\% G/A with levels of TNF-a were not detected.; and $59.1 \% \mathrm{G} / \mathrm{G}$ with median plasma TNF-a of $15.1 \mathrm{pg} / \mathrm{ml}$ (1.7-74.9 pg/ml). The mortality rate was A/A $32 \%, \mathrm{G} / \mathrm{A} 20 \%$, and $\mathrm{G} / \mathrm{G} 38 \%{ }^{24}$ In contrast to this study, only $7.5 \%$ with G/A or heterozygous alleles were found and all were survived. The median level of TNF- $a$ in G/A subjects was slightly higher than in $\mathrm{G} / \mathrm{G}$ subjects, both in the standard and high protein groups, but there was no difference between heterozygous and homozygous subjects. This is important because none of our subjects were homozygous TNF- $a-308 \mathrm{~A} / \mathrm{A}$. In previous studies, subjects with A/A or TNF2 had higher TNF- $\alpha$ levels and a higher risk of death. ${ }^{13}$

In the standard protein group, PELOD score was significantly lower in G/A than $G / G$ groups on day 2 . The average PELOD score of the G/A subjects decreased dramatically from day 1 to 3 , from 16.3 to 8.3 and to 6 , meanwhile there was no significant PELOD scores improvement in subjects with $\mathrm{G} / \mathrm{G}$. In the high protein group, PELOD scores of G/A subjects showed clinical improvement with 24.7 to 17.3 and to 13.3 , but there is no difference from $\mathrm{G} / \mathrm{G}$ subjects.

Overall, subjects with TNFA-308 G/A gene polymorphisms had better outcomes, regarding nitrogen balance, PELOD score, length of stay, and duration of ventilator use. These results differ from previous studies that found the TNF- $\alpha-308 \mathrm{~A}$ alleles to be associated with poor outcomes from infectious and inflammatory diseases, including malaria, meningococcal disease, and celiac disease. ${ }^{23}$ A study in Thailand found no association between the TNFA gene polymorphism with sepsis or septic shock. This result may be due to the absence of differences in the frequency of the TNFA gene polymorphism occurrences between the case and control groups because of the small number of samples. ${ }^{14}$

This is the first study that reported a description of the TNFA-308 gene polymorphism in Indonesia. Limitations might be because of the small number of subjects and lack of diversity in the population. Researchers gave a high protein nutrient for only three days and observed the effects. The short administration period might be the cause of the insignificant association between the protein intake and PELOD scores in this study. Researchers suggested conducting a similar study by considering the ratio of nonprotein calories and protein calories by using indirect calorimetry for caloric needs calculations. Further research implementing longer administration of the high protein nutrient may also be needed to determine the time-effect relationship. Genetic studies of sepsis require diverse populations and should include control subjects.

From this study, researchers concluded that a high protein intervention did not significantly decrease the PELOD score, length of stay, and duration of ventilator use in both groups. In addition, the TNFA308 gene polymorphism showed only the decreasing PELOD score on days 2 to 3 in the control group. In the intervention group, it was only associated with the decreasing duration of ventilator use.

mji.ui.ac.id 


\section{Conflicts of Interest}

Sri Widia Azraki Jusman is editorial board member but was not involved in the review or decision process for the article.

\section{Acknowledgment}

The authors would like to thank and expresses appreciation to the Department of Child Health, Faculty of Medicine, Universitas Sumatera Utara, Universitas Indonesia, and Haji Adam Malik Hospital.

\section{Funding Sources}

None.

\section{REFERENCES}

1. Wong HR, Nowak JE, Standage SW, Oliveira CF. Sepsis. In: Fuhrman BP, Zimmerman JJ, Carcillo JA, Clark RS, Rotta AT, Tobias JD, Relvas MS, et al, editors. Pediatric critical care. 4th ed. Philadelphia: Elsevier; 2011. p. 1413-29.

2. Riley C, Wheeler DS. Prevention of sepsis in children: a new paradigm for public policy. Crit Care Res Pract. 2011;2012:437139.

3. Hadinegoro SR, Chairulfatah A, Latief A, Pudjiadi AH, Malisie RF, Alam A. National guidelines for the medical services of Indonesian pediatricians: diagnosis and management of sepsis in children. Jakarta: Indonesian Pediatrician Association. 2016. p. 1-7. Indonesian.

4. Briassoulis G, Zavras N, Hatzis T. Malnutrition, nutritional indices, and early enteral feeding in critically ill children. Nutrition. 2001;17(7-8):548-57.

5. Weijs PJ, Cynober L, DeLegge M, Kreymann G, Wernerman J, Wolfe RR. Proteins and amino acids are fundamental to optimal nutrition support in critically ill patients. Crit Care. 2014;18(6):591.

6. Gerlach AT, Murphy C. An update on nutrition support in the critically ill. J Pharm Pract. 2011;24(1):70-7.

7. Rhodes A, Evans LE, Alhazzani W, Levy MM, Antonelli M, Ferrer $R$, et al. Surviving sepsis campaign: international guidelines for management of severe sepsis and septic shock: 2016. Crit Care Med. 2017;45(3):486-552.

8. Kumar S, Rizvi M. Prognostic serum tumor necrosis factor- $a$ in paediatric patients with sepsis. J Infect Dev Ctries. 2009;3(6):437-41.

9. Holmes CL, Russell JA, Walley KR. Genetic polymorphism in sepsis and septic shock, role in prognosis and potential for therapy. Chest. 2003;124(3):1103-15.

10. Mira JP, Cario A, Grall F, Delclaux C. Loosser MR, Heshmati F, et al. Association of TNF2, a TNF-a promoter polymorphism, with septic shock susceptibility and mortality: a multicenter study. JAMA. 1999;282(6):561-8.

11. Nurnaningsih. Nutrition in critically ill children. In Pudjiadi
AH, Latief A, Budiwardhana N, editors. Emergency Pediatric Textbooks. IDAI. 2013. p. 173-86. Indonesian.

12. Honna L, Triratna S, Triwani, Theodorus. Use of pediatric logistic organ dysfunction (PELOD) in determining prognostic among pediatric intensive care unit patients. Pediatr Indones. 2010;50(6):347-50.

13. Reid CL, Perrey C, Pravica V, Hutchinson IV, Campbell IT. Genetic variation in proinflammatory and anti-inflammatory cytokine production in multiple organ dysfunction syndrome. Crit Care Med. 2002;30(10):2216-21.

14. Phumeetham S, Chat-Uthai N, Manavathongchai M, Viprakasit V. Genetic association study of tumor necrosis factor-alpha with sepsis and septic shock in Thai pediatric patients. J Pediatr (Rio J). 2012;88(5):417-22.

15. Winiati E, Kosim MS, Supriatna M. Predicting PICU patient survival prognosis: pediatric logistic organ dysfunction vs pediatric index of mortality score. Pediatr Indones. 2012;52(3):165-9.

16. te Braake FW, van den Akker $\mathrm{CH}$, Wattimena DJ, Huijmans JG, van Goudoever JB. Amino acid administration to premature infants directly after birth. J Pediatr. 2005;147(4):457-61.

17. Reynolds RM, Bass KD, Thureen PJ. Achieving positive protein balance in the immediate postoperative period in neonates undergoing abdominal surgery. J Pediatr. 2008;152(1):63-7.

18. Geukers VG, Oudshoorn JH, Taminiau JA, van der Ent CK, Schilte $P$, Ruiter AF, et al. Short-term protein intake and stimulation of protein synthesis in stunted children with cystic fibrosis. Am J Clin Nutr. 2005;81(3):605-10.

19. Cross-Bu JA, Hamilton-Reeves J, Patel JJ, Morris CR, Hurt RT. Protein requirements of the critically ill pediatric patient. Nutr Clin Pract. 2017;32 (1 suppl):128S-41S.

20. Leteurtre S, Duhamel A, Grandbastien B, Proulx F, Cotting J, Gottesman R, et al. Daily estimation of the severity of multiple organ dysfunction syndrome in critically ill children. CMAJ. 2010;182(11):1181-7.

21. Azis AL. Nutritional support for severely ill children. Division of pediatric emergency department of Pediatrics FK Unair / Dr. Sutomo Hospital - Surabaya. p. 1-24. Indonesian.

22. Van Waardenburg DA, de Betue CT, van Goudoever JB, Zimmerman LJ. Nutritional effects of early administration of a protein and energy enriched formula in critically ill infants; a randomized controlled trial [thesis]. Maastricht: Maastricht University. 2008. Chapter 6 and 7. p. 85-100.

23. Dinata K, Runtunuwu AL, Mandei JM, Lolumbulan JH. Correlation between tumor necrosis factor-alpha and septic shock in children. Pediatr Indones. 2013;53(1):1-5.

24. Botrán M, López-Herce J, Mencía S, Urbano J, Solana MJ, Garcia A. Enteral nutrition in the critically ill child: comparison of standard and protein-enriched diets. J Pediatr. 2011;159(1):2732.e1. 